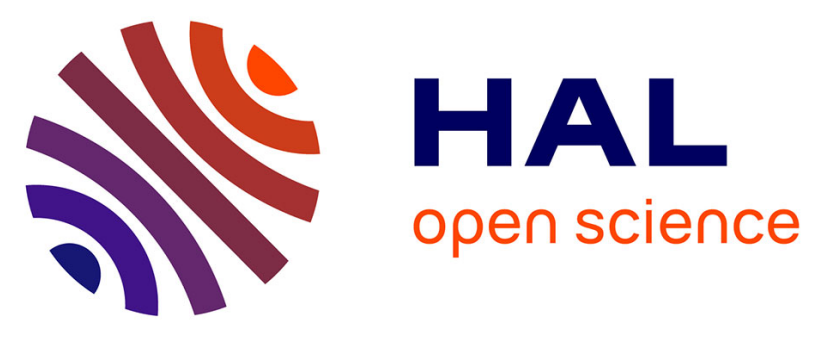

\title{
Changes in soil microbial substrate utilization in response to altered litter diversity and precipitation in a Mediterranean shrubland
}

\author{
Ammar Shihan, Stephan Hättenschwiler, Alexandru Milcu, François-Xavier \\ Joly, Mathieu Santonja, Nathalie Fromin
}

\section{To cite this version:}

Ammar Shihan, Stephan Hättenschwiler, Alexandru Milcu, François-Xavier Joly, Mathieu Santonja, et al.. Changes in soil microbial substrate utilization in response to altered litter diversity and precipitation in a Mediterranean shrubland. Biology and Fertility of Soils, 2017, 53 (2), pp.171-185. 10.1007/s00374-016-1166-9 . hal-01481169

HAL Id: hal-01481169

https://hal-univ-rennes1.archives-ouvertes.fr/hal-01481169

Submitted on 14 May 2018

HAL is a multi-disciplinary open access archive for the deposit and dissemination of scientific research documents, whether they are published or not. The documents may come from teaching and research institutions in France or abroad, or from public or private research centers.
L'archive ouverte pluridisciplinaire HAL, est destinée au dépôt et à la diffusion de documents scientifiques de niveau recherche, publiés ou non, émanant des établissements d'enseignement et de recherche français ou étrangers, des laboratoires publics ou privés. 


\title{
Changes in soil microbial substrate utilization in response to altered litter diversity and precipitation in a Mediterranean shrubland
}

\author{
Ammar Shihan ${ }^{1,2}$ - Stephan Hättenschwiler ${ }^{1}$ - Alexandru Milcu ${ }^{1,3} \cdot$ François-Xavier Joly ${ }^{1}$ Mathieu Santonja $^{4,5}$. \\ Nathalie Fromin ${ }^{1,6}$ \\ 1 Centre d'Ecologie Fonctionnelle et Evolutive (CEFE), UMR 5175, CNRS - Université de Montpellier - Université Paul-Valéry \\ Montpellier - EPHE, 1919 route de Mende, 34293 Montpellier Cedex 5, France \\ 2 Department of Renewable Natural Resources and Environment, Faculty of Agricultural, Aleppo University, Aleppo, Syria \\ 3 Ecotron Européen de Montpellier, Unité Propre de Service 3248, Centre National de la Recherche Scientifique (CNRS), Campus \\ Baillarguet, 34980 Montferrier-sur-Lez, France \\ 4 Institut Méditerranéen de Biodiversité et d'Ecologie (IMBE), Aix Marseille Université, CNRS, IRD, Avignon Université, CS 80249, Case 4, \\ 13331, Marseille Cedex 03, France \\ 5 Present address: Université Rennes 1 - UMR CNRS 6553 ECOBIO, Avenue du Général Leclerc, Campus de Beaulieu, 35042 Rennes, France \\ 6 Present address: PROMES-CNRS, 7 rue du Four Solaire, 66120 Odeillo, France
}

\begin{abstract}
This study aimed at quantifying the consequences of reduced precipitation and plant diversity on soil microbial community functioning in a Mediterranean shrubland of southern France. Across a natural gradient of shrub species diversity, we established a total of 92 plots $(4 \times 4 \mathrm{~m})$ with and without a moderate rain exclusion treatment of about $12 \%$ of total precipitation. Shrub diversity included all possible com-binations of the four dominant species (Cistus albidus, Quercus coccifera, Rosmarinus officinalis a n d Ulex parviflorus). Respective leaf litter mixtures of these species combinations were exposed in all plots over 2 years. We quan-tified how litter species richness and the reduction in precipi-tation affected the soil microbial substrate utilization (mea-sured by $\mathrm{CO}_{2}$ evolution using the MicroResp method) on soil samples collected underneath each individual litter mixture after 1 and 2 years of decomposition. Moderate precipitation reduction had a minor impact, but litter species richness and the dissimilarity in phenolic concentrations (estimated using Rao's quadratic entropy) showed a positive effect on the di-versity of substrates metabolized by the microbial communi-ties. Moreover, litter species richness increased soil microbial activity by increasing the catabolic diversity of the soil micro-bial community. These effects were mostly driven by the pres-ence of Quercus and Ulex leaf litter, which at the same time reduced microbial metabolic dominance, while the presence of Rosmarinus had opposite effects. Our data suggest that plant species loss can have stronger effects on the functioning of soil microbial communities than moderate drought, with potentially important feedbacks on biogeochemical cycling in Mediterranean shrubland ecosystems.
\end{abstract}

Keywords Climatechange ·Mediterraneanecosystem -Litter decomposition · Functional diversity · Soil microbial activity $\cdot$ MicroResp ${ }^{(\mathrm{TM})}$ 


\section{Introduction}

Anthropogenically induced changes in biodiversity and precipitation patterns are mutually impacting the functioning of a wide range of ecosystem processes (Field et al. 2015). However, the understanding of how these two drivers of global change interact and affect ecosystem functioning is limited. In particular, the consequences for the functioning of the soil microbial communities, known to exhibit a strong control over the carbon (C) and nutrient cycles, have been little explored (Rodríguez-Loinaz et al. 2008; Chapman and Newman 2009).

There is increasing evidence that plant diversity underpins the functioning of ecosystems (Cardinale et al. 2012; van der Plas et al. 2016). Different plant species produce litter with a wide range of distinct morphological and chemical characteristics (Cornwell et al. 2008). The emerging complex interactions between direct effects of plant community composition on the quality and quantity of litter entering the soil system and indirect effects mediated by the responses of the decomposer communities (Wardle 2002) make the identification of general patterns for the interaction between litter characteristics and soil microbial functioning a considerable challenge. Moreover, plant diversity impacts on microclimatic conditions (Lorentzen et al. 2008) are known to be major driving factors of microbial processes (Freiberg 1998) affecting C and nitrogen (N) cycling. In general, it appears that plant functional diversity is more important than species richness for the understanding of how plants and soil biota interact (Johnson et al. 2003; Porazinska et al. 2003; De Deyn et al. 2004; Salamon et al. 2004). The majority of studies assessing the role of litter diversity for processes related to decomposition demonstrated that biodiversity effects are mostly driven by the functional traits represented in litter mixtures, independently of how many species are contributing to the mixtures (e.g., Wardle et al. 1997; Ball et al. 2008; Barantal et al. 2014; Handa et al. 2014; but see Chen et al. 2015). Two broadly complementary functional trait-based approaches are currently being used. One approach aims at identifying the dominant traits driving the ecosystem processes and can be related to the "biomass-ratio hypothesis" (Grime 1998) stating that the effect of any species on a given ecosystem process is proportional to the relative abundance of that species in the community (or in the litter mixture). Accordingly, plant community-weighted mean (CWM) traits have been found to be relevant predictors of plant community effects on certain ecosystem processes. The second approach aims at quantifying the functional diversity of communities by assessing the variety, range, and evenness of the traits present in communities (or in the litter mixture), making reference to the niche complementarity hypothesis, since a greater range of trait values is generally considered to indicate less niche overlap (Petchey and Gaston 2006; Díaz et al. 2007). However, functional identity and functional diversity are not mutually exclusive in affecting ecosystem processes (Violle et al. 2007) such as primary productivity (Schumacher and Roscher 2009; Roscher et al. 2012) or litter decomposition (Mokany et al. 2008; Barantal et al. 2011; Handa et al. 2014). Although these functional traitbased approaches have primarily been developed at the level of the plant community, several studies showed that they can be also useful in the understanding of diversity effects on litter decomposition (Epps et al. 2007; Meier and Bowman 2008, 2010) or other soil processes (Meier and Bowman 2008, 2010).

Soil communities have been shown to vary as a function of the litter resources deposited at the soil surface (e.g., Ayres et al. 2009; Carrillo et al. 2011; Milcu et al. 2013), and thus, they may be modified with alterations in the species composition of the litter layer. There is compelling evidence that litter functional identity and diversity are important drivers of litter decomposition (Cornwell et al. 2008; Handa et al. 2014), with species-rich plant communities supporting more complementary microbial communities (Eisenhauer et al. 2010). A higher microbial diversity could translate in a more efficient use of organic substrates because of a greater functional niche exploitation (Loreau 2001). As a further consequence of more complementary niche exploitation, microbial biomass may increase in species-rich litter mixtures offering higher resource diversity (Chapman and Newman 2009). Indeed, results from plant diversity experiments documented higher soil microbial biomass and activity with increasing plant species and functional diversity (Eisenhauer et al. 2010; Milcu et al. 2013; Vogel et al. 2013; Steinauer et al. 2015).

The predictability of how plant diversity loss is affecting $\mathrm{C}$ processing in the soil is difficult also because concomitant changes in environmental factors such as temperature or precipitation may interact with changes in plant diversity. Mediterranean ecosystems are considered to be particularly sensitive to changes in precipitation (Lionello and Giorgi 2007) and altered frequency of rainfall events and altered frequency of rainfall events (Gao et al. 2006). For example, the indirect drought effects on litter decomposition via changes in litter quality may be substantial even without a change in plant diversity and should be considered along with direct soil moisture-driven effects for accurate predictions of litter decomposition in Mediterranean ecosystems under climate change (García-Palacios et al. 2016). Several studies evaluated the response of soil microbial properties to plant diversity (e.g., Eisenhauer et al. 2010; Milcu et al. 2013) or to climate change factors (in the Mediterranean context, see Bérard et al., 2012; Pailler et al. 2014; Yuste et al. 2014). However, very few studies addressed the combined effects of plant diversity and climate change factors (Niklaus et al. 2007; Bloor and Bardgett 
2012; Eisenhauer et al. 2013; Vogel et al. 2013). A synthesis of 12 studies with orthogonal manipulations of global environmental change factors and plant diversity (Takhur et al. 2015) showed that effects of environmental change factors (such as drought or nutrient enrichment) and of plant diversity on the soil microbial biomass were independent with no evidence for interactions. However, very little experimental evidence exists for Mediterranean ecosystems, where both decreasing precipitation and biodiversity loss are expected to occur simultaneously in the forthcoming decades. A study by Lloret et al. (2015) showed that the quite drastic effects of drought via plant mortality increased the richness and changed the composition in soil microbial community of Mediterranean woodlands. Despite the recent emergence of methodologies characterizing the functional differences between microbial communities (e.g., MicroResp ${ }^{\mathrm{TM}}$, Chapman et al. 2007; Campbell et al. 2008), a functional assessment of the impact of the interaction between diversity and reduced precipitation is currently lacking.

Here, we assessed how experimentally reduced precipitation in a Mediterranean shrubland ecosystem affected the functioning of soil microbial community along a natural gradient of plant diversity (one to four woody plant species). We hypothesized that (i) an increase in litter species richness and functional dissimilarity (Rao's quadratic entropy; Botta-Dukát 2005; Epps et al. 2007) will lead to more complementary microbial communities that are able to degrade multiple substrates more efficiently and (ii) the soil microbial communities associated to more diverse litter mixtures are also more resistant to reduced precipitation. To test our hypotheses, we characterized the ability of soil microbial communities to respire on 15 different $\mathrm{C}$ substrates and to decompose cellulose paper in the soil associated to all possible combinations of litter mixtures of four woody shrub species (Cistus albidus, Quercus coccifera, Rosmarinus officinalis, and Ulex parviflorus) dominating at our study site, in a fully factorial rainfall exclusion experiment, and after 1 and 2 years of in situ decomposition. Furthermore, we explored how the soil microbial substrate utilization was affected by litter species richness, litter species composition, and identity as well as functional dissimilarity of the litter traits using Rao's diversity metric and CWM traits.

\section{Materials and methods}

\section{Study site}

The study site was located in the Massif de l'Etoile near Marseille, France $\left(43^{\circ} 22^{\prime} \mathrm{N}, 5^{\circ} 25^{\prime} \mathrm{E}\right)$ at $275 \mathrm{~m}$ above sea level (see Montès et al. (2008) for a detailed description of the site). The mean annual precipitation is $552 \mathrm{~mm}$, and the mean annual temperature is $14.6^{\circ} \mathrm{C}$. The soil is classified as a shallow rendzina developed over limestone bedrock with
$65.7 \%$ of stones in the top $50 \mathrm{~cm}$. Soil texture, C, N, P, $\mathrm{Ca}^{2+}, \mathrm{Mg}^{2+}, \mathrm{Na}^{+}, \mathrm{K}^{+}, \mathrm{Fe}^{3+}, \mathrm{Mn}^{2+}, \mathrm{Al}^{3+}$ and $\mathrm{Pb}^{2+}$ concentrations, cation exchange capacity (CEC), and $\mathrm{pH}$ were analyzed for each of the 92 individual plots by the Laboratoire d'Analyse des Sols (INRA Arras) and are presented in Supplementary Table S1.

The vegetation is a woody shrub-dominated "garrigue" with individual shrub heights ranging from 0.2 to $1.4 \mathrm{~m}$ and a cover between 25 and $95 \%$ (see Montès et al. 2008 for further details). Four woody shrub species dominate the community: Q. coccifera L. (Quercus, with an average cover across all plots of $36 \%$ ), C. albidus L. (Cistus, $18 \%$ ), U. parviflorus Pourr. (Ulex, $10 \%$ ), and R. officinalis L. (Rosmarinus, $9 \%$ ).

\section{Experimental design}

Ninety-two $4 \times 4 \mathrm{~m}$ plots were selected based on plant community composition in order to include all 11 possible combinations of the four dominant shrub species and their single species patches (a total of 15 treatments). Each of the 15 different plant combinations was replicated six times, except for the four-species mixture that was replicated eight times. Half of the plots (four replicates for the four-species mixtures and three replicates for all other treatments) were equipped with a rain exclusion device that consisted in an aluminum frame holding stainless steel gutters at $2 \mathrm{~m}$ above the ground and covering $40 \%$ of the plot surface. A supplementary PVC gutter and a pipe mounted at the border of the frame allowed to evacuate the rainwater away from the plots. The remaining plots were used as control plots that were also equipped with gutters but mounted inversely in order to diminish interception of rainfall. The experimental rain exclusion was set up in October 2011. The exact amount of precipitation excluded was estimated using (i) rain gauges installed at ground level underneath the gutters in both control and rain-excluded plots and (ii) TDR100 probes (Campbell Scientific Inc., Logan, Utah) installed in seven control and eight rain-excluded plots at $10 \mathrm{~cm}$ soil depth and by (iii) determining the gravimetric humidity in the soil sampled in control and excluded plots. Compared to control plots, the rain exclusion plots received on average $12 \pm 2 \%$ SEM less rainfall. This exclusion resulted in an average lower soil humidity of $-6.5 \%$ (that could reach between -13 and $-24 \%$ during rain events) at $10 \mathrm{~cm}$ soil depth between control and rain exclusion plots (determined by permanently installed TDR probes; Supplementary Fig. S1) (Santonja et al. submitted).

\section{Litter decomposition and soil sampling}

Because the relative contribution of the different species is not even at our field site, and in order to standardize the litter material decomposing on the soil surface as well as the stage of decomposition across all plots, the microbial substrate 
utilization was estimated from the soil (down to $5 \mathrm{~cm}$ depth) under which the litter mixtures decomposed in field mesocosms. Freshly shed leaves from Cistus, Quercus, Rosmarinus, and the smallest distal twigs from Ulex (this species has photosynthesizing stems rather than leaves) were collected during peak leaf litterfall from June to July in 2011 using litter traps suspended under the shrubs that were emptied regularly. This material was air-dried and pooled to prepare single batches of leaf litter for the four species. A common leaf litter material from Pinus halepensis (a species that does not occur at our study site but is typical for the Mediterranean area) was collected like for the other species in an adjacent forest site and used in the incubation experiment in an attempt to separate the direct effects of decomposing leaf litter from the overall effects of the living plants (for example through root-driven processes).

The litters used in the decomposition experiment (4 single shrub species and 11 possible combinations of these four species) were composed of equal amounts of each contributing species with a total of $6 \mathrm{~g}$ of dry leaf litter (or also $6 \mathrm{~g}$ for the single species treatments) per mesocosm. These litters were incubated in the plots with the corresponding shrub species composition (for instance, the Quercus/Cistus mixtures were incubated in the plots where these two species but not Rosmarinus or Ulex occurred). Additionally, mesocosms with $6 \mathrm{~g}$ of Pinus litter were incubated in all the 92 plots. Mesocosms consisted in "open-bottom" plastic cylinders $(8 \mathrm{~cm}$ in diameter and $5 \mathrm{~cm}$ tall) that were randomly placed and fixed on the bare soil surface (naturally occurring litter was removed previously) within the central $4 \mathrm{~m}^{2}$ of each plot. Two openings $(12 \times 3 \mathrm{~cm})$ were cut on the side of the plastic cylinders and covered with $10 \mathrm{~mm}$ mesh. These side openings and the open bottom of the cylinders allowed full access to the litter for the naturally occurring soil and litter-dwelling fauna. The top of the cylinders was covered with $1 \mathrm{~mm}$ mesh to avoid canopy litter mixing with the target litter while allowing the passage of rain water. Seven mesocosms of plot-specific leaf litter and two mesocosms of Pinus litter were prepared and installed in the field for each plot in December 2011.

We retrieved four replicates in December 2012 and three replicates in December 2013 of plot-specific leaf litter. The two mesocosms filled with Pinus litter were both collected after 2 years in December 2013. The remaining leaf litter was collected from the plastic cylinders after 1 and 2 years of field exposure (see Santonja et al. submitted for results). After litter removal, we collected the underlying top soil to about $5 \mathrm{~cm}$ depth, yielding a total of 828 soil samples (368 samples after 1 year and 276 samples after 2 years for plotspecific litter and 184 samples after 2 years for Pinus litter). The soil samples for the microbial analyses were air-dried in the dark at $25^{\circ} \mathrm{C}$ for 10 days and sieved through a $2-\mathrm{mm}$ sieve. Equal amounts of soil of the three or four replicate samples (plot-specific litter) or two replicate samples (Pinus litter) from each plot and at each sampling date were mixed and homogenized to produce representative composite samples. These composite samples were stored in a dry and dark storage room until analysis.

\section{Leaf litter traits}

Eight leaf litter functional characteristics (traits) of the shrub species, known from the literature to correlate with litter decomposition rates, were determined: the concentrations of total $\mathrm{C}(\mathrm{C}), \mathrm{N}(\mathrm{N})$, phosphorus $(\mathrm{P})$, lignin, total phenolics (Phenolics), dissolved organic C (DOC), and total dissolved N (TDN) [Joly et al. (2016) underlined the critical role of soluble litter compounds to explain litter mixture effects on soil microbial properties], as well as the water holding capacity (WHC) (Supplementary Table S2). The communityweighted mean traits of litter mixtures $\left(\mathrm{C}_{\mathrm{CWM}}, \mathrm{N}_{\mathrm{CWM}}\right.$, $\mathrm{P}_{\mathrm{CWM}}$, Lignin ${ }_{\mathrm{CWM}}$, Phenolics $\mathrm{CWM}_{\mathrm{C}}$, Lignin: $\mathrm{N}_{\mathrm{CWM}}$, $\mathrm{DOC}_{\mathrm{CWM}}, \mathrm{TDN}_{\mathrm{CWM}}$, and $\mathrm{WHC}_{\mathrm{CWM}}$ ) were calculated as the average trait values of litter mixtures according to the following equation (Garnier et al. 2004): $\operatorname{TraitCWM}=\sum_{i=1}^{n} B_{i} \times$ trait ${ }_{i}$, where $B_{i}$ is the relative abundance for species $i$ and trait $_{i}$ is the trait value for species $i$. The functional dissimilarity was calculated according to the Rao index (Epps et al. 2007) for each litter mixture $\left(\mathrm{C}_{\mathrm{FD}}, \mathrm{N}_{\mathrm{FD}}, \mathrm{P}_{\mathrm{FD}}\right.$, Phenolics $\mathrm{FD}$, Lignin ${ }_{\mathrm{FD}}$, Lignin $/ \mathrm{N}_{\mathrm{FD}}, \mathrm{DOC}_{\mathrm{FD}}, \mathrm{TDN}_{\mathrm{FD}}$, and $\mathrm{WHC}_{\mathrm{FD}}$ ) as follows: Trait $_{\mathrm{FD}}=\sum_{i=1}^{n} \sum_{j=1}^{n}$ pipj $\times d i j$ (using the dbFD function of the R package "FD") where $p i$ and $p j$ are the relative abundance for shrub species $i$ and $j$ in the litter mixture and dij the Euclidian distance between species $i$ and $j$ for the trait considered. Because the measured traits differ in their numerical value ranges, standard normal deviates (so as to get an expected value of zero and a variance of one for traits values) were used to calculate functional dissimilarity.

\section{Soil microbial substrate utilization by MicroResp}

MicroResp ${ }^{\mathrm{TM}}$ offers a convenient, rapid, and sensitive method for the determination of soil microbial substrate utilization which allowed us to estimate the microbial community functional diversity (Campbell et al. 2008). Its application in a number of case studies has demonstrated its utility in a wide range of soils and land cover types (Chapman et al. 2007; Creamer et al. 2016). About $0.49 \mathrm{~g}$ dry weight of soil was incubated in triplicate with $1.5 \mathrm{mg} \mathrm{C} \mathrm{g}^{-1}$ soil (except for the low-soluble phenolic acids and cellulose for which $0.75 \mathrm{mg} \mathrm{C}$ $\mathrm{g}^{-1}$ soil was added) of 15 different $\mathrm{C}$ substrates, plus one control with deionized water, so as to reach $80 \%$ of the field capacity in 96-DeepWell Microplates (Fisher Scientific E39199). Carbon substrates included three carbohydrates (D- 
glucose, xylan, cellulose, by order of complexity), one amine ( $N$-acetyl-glucosamine), five amino acids (L-asparagine, Lglutamine, L-lysine, L-serine, L-glycine), three carboxylic acids (malic acid, oxalic acid, uric acid), and three phenolic acids (caffeic acid, which is an intermediate in lignin biosynthesis, syringic acid, and vanillic acid which is a by-product during the degradation of polyphenols by fungi). Cresol red gel detection plates were prepared as recommended by the manufacturer. After an initial 2-h pre-incubation at $25{ }^{\circ} \mathrm{C}$ in the dark, each deepwell microplate was covered with a detection plate using a silicone gasket (MicroResp ${ }^{\mathrm{TM}}$, Aberdeen, UK). The assembly was secured with a clamp and incubated for four additional hours. Optical density at $590 \mathrm{~nm}\left(\mathrm{OD}_{590}\right)$ was measured for each detection well before and after incubation using a Victor 1420 Multilabel Counter (PerkinElmer, Massachusetts, USA). Final $\mathrm{OD}_{590}$ were normalized using pre-incubation $\mathrm{OD}_{590}$ and converted as substrate induced respiration rates expressed in microgram $\mathrm{C}-\mathrm{CO}_{2}$ respired per gram of soil per hour.

The respiration rates for the different $\mathrm{C}$ substrates were summed across all 15 substrates (sum15) as a proxy of the global metabolic activity, and standardized rate for each substrate was computed as the rate measured for this substrate divided by sum15, as proposed by (Leff et al. 2012). For each plot, a Shannon metabolic diversity index was computed as $H^{\prime}=-\sum_{i=1}^{15} p i \times \log (p i)$, and a Simpson metabolic dominance index was computed as $D=\sum_{i}^{j} p i 2$, where $(p i)$ is the standardized respiration rate for substrate $(i)$.

\section{Decomposition of cellulose paper (DCP)}

Cellulose paper disks $(0.20 \pm 0.009 \mathrm{~g})$ with a diameter of $55 \mathrm{~mm}$ (filter paper qualitative $388,84 \mathrm{~g} / \mathrm{m}^{2}$, Sartorius) were weighted, enclosed between two nylon nets $(0.2 \mathrm{~mm}$ mesh size), and incubated with $20 \mathrm{~g}$ of soil in 90 -mm-diameter Petri dishes. The soil was wetted with deionized water so as to reach $80 \%$ of field capacity and then placed in the dark for 3 weeks at a constant temperature of $25^{\circ} \mathrm{C}$ (Wardle et al. 1999). After 21 days of incubation, the remaining cellulose was recovered, cleaned gently with a brush in deionized water, and then oven dried to constant mass $\left(65^{\circ} \mathrm{C}\right)$ to determine remaining cellulose dry mass and cellulose mass loss. The cellulose disks were then burned in a muffle oven $\left(550^{\circ} \mathrm{C}\right)$ to determine ash-free dry mass to correct for adhering mineral soil. DCP was measured from soil samples underneath plot-specific litter only but not from soil samples underneath Pinus litter.

\section{Data analysis}

Statistical analyses were performed with the R software (version 3.1.0, The R Foundation for Statistical Computing 2014) with significance levels indicated as for $p<0.10, *$ for $p<0.05$, ** for $p<0.01$, and $* * *$ for $p<0.001$. We used a multiple linear model approach ( $I m$ function from the "stats" package) to determine the most parsimonious models predicting the microbial parameters (sum15, $H^{\prime}, D$, and DCP). For each microbial response variable, we carried out four distinct statistical models aiming to assess the importance of experimental treatments, species identity, functional diversity of litter traits (Rao's quadratic entropy), and CWM of litter traits, respectively. The first model tested the impact of precipitation treatments (control vs. precipitation reduction), species richness, species composition, and their interactions. The second model tested the impact of species identity (i.e., the presence/ absence of a particular species), precipitation treatment, and their interactions. The third and fourth models tested the impact of functional diversity (traits $\mathrm{FD}_{\mathrm{FD}}$ ) and the CWM (traits $\mathrm{CWM}_{\mathrm{CW}}$ ) of individual traits, respectively. Given the high number of litter traits measured, for the third and fourth models, we preselected four traits using the randomForest function of the eponymous package, which classifies predictor variables by importance (Cutler et al. 2007). To take into account the effects of soil heterogeneity between plots, we used the scores of the first axis of a PCA analysis of plot-specific soil characteristics [soil texture, $\mathrm{pH}, \mathrm{CEC}$, and the concentrations of $\mathrm{C}, \mathrm{N}, \mathrm{P}$, calcium, magnesium, sodium, potassium, iron, lead, manganese, and aluminum (see Supplementary Table S1)], named Soil-PCA (accounting for $40.3 \%$ of the total variability, see Supplementary Fig. S2) as covariable in all models. The full models were then simplified to determine the most parsimonious models using the stepAIC function of the "MASS" package, an established model selection procedure with both forward and backward selection algorithms, which ranks all candidate models (all possible combinations of initial explanatory variables included in the full model) based on lowest AICs (Crawley 2013). We present the $r^{2}$ and AIC values for both the full model (with all initial explanatory variables) and the most parsimonious model. Relationships between soil microbial parameters (sum15, $H^{\prime}, D$, and DCP) and individual litter mixture parameters (litter species richness, trait ${ }_{\mathrm{CWM}}$, or of trait $_{\mathrm{FD}}$ ) were plotted using linear regressions across all plots. To meet the assumption of normal distribution of residuals, we applied a $\log$ transformation for sum 15 values and a square root transformation for DCP values.

As sum15, $H^{\prime}$, and litter species richness turned out to be correlated, and in order to test our first hypotheses, we also performed a path analysis using the "lavaan" package (Rosseel 2012) to assess whether the effect of species richness on sum 15 was mediated by a richness to $H^{\prime}$ pathway. Good model fit was indicated by nonsignificant differences between the predicted and observed covariance matrices ( $\chi^{2}$ tests with $p>0.05$ ), lower root mean squared error approximation (RMSEA $<0.1$ ), higher comparative fit index (CFI > 0.90) (Grace 2006; Rosseel 2012), and an $\mathrm{AIC}_{\text {model }}<\mathrm{AIC}_{\text {unrestricted_model }}$. 


\section{Results}

\section{Effects of litter species richness and composition on microbial substrate utilization}

The global metabolic activity that included respiration rates of all 15 substrates (sum15) in the soil from single species litter treatments varied only little after 1 year of decomposition (between $47.0 \pm 8.6$ and $51.1 \pm 7.0 \mu \mathrm{g} \mathrm{C}-\mathrm{CO}_{2} \mathrm{~g}^{-1}$ of soil $\mathrm{h}^{-1}$ ) but considerably more after 2 years of decomposition (between $37.0 \pm 6.0$ and $50.1 \pm 10.2 \mu \mathrm{g} \mathrm{C}-\mathrm{CO}_{2} \mathrm{~g}^{-1}$ of soil $\mathrm{h}^{-1}$ ) across control and rain-excluded plots (Supplementary Table S3). When all litter mixture treatments were included, the overall range in sum 15 values was wider with the highest rates measured under the Cistus/Ulex mixture $\left(66.6 \pm 4.6 \mu \mathrm{g} \mathrm{C}-\mathrm{CO}_{2} \mathrm{~g}^{-1}\right.$ soil h$\left.^{-1}\right)$ and the lowest rates measured under the Quercus/Ulex/Rosmarinus mixture $\left(37.6 \pm 4.3 \mu \mathrm{g} \mathrm{C}-\mathrm{CO}_{2} \mathrm{~g}^{-1}\right.$ soil $\left.\mathrm{h}^{-1}\right)$ after 1 year of decomposition across both precipitation treatments (Supplementary Table S3). Neither species richness nor species composition affected total microbial activity after 1 year (Table 1). After 2 years of decomposition, the range in sum 15 values covered was comparable to that after 1 year of decomposition, with the highest values measured under the Quercus/Ulex mixture $\left(64.0 \pm 9.4 \mu \mathrm{g} \mathrm{C}-\mathrm{CO}_{2} \mathrm{~g}^{-1}\right.$ soil $\left.\mathrm{h}^{-1}\right)$ and the lowest under

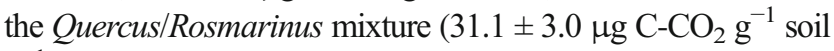
$\mathrm{h}^{-1}$ ) across both precipitation treatments. In year 2, species richness still did not affect sum15, but there was a significant litter composition effect (Table 1). The plot-specific soil characteristics (Soil-PCA) accounted for most of the observed variation in sum 15 in both years of sampling, although only marginally significantly after 1 year of decomposition (Table 1). The mean sum15 values measured under Pinus litter after 2 years of decomposition ranged between $43.1 \pm 5$ and $79.8 \pm 12.5 \mu \mathrm{g} \mathrm{C}-\mathrm{CO}_{2}$ $\mathrm{g}^{-1}$ soil $\mathrm{h}^{-1}$. There was a similar strong effect of plot-specific soil characteristics (Soil-PCA) on sum15 under Pinus compared to plot-specific leaf litter, but species richness or composition had no effect (Table 1).

Microbial metabolic diversity indices were not affected by rain exclusion (Table 1), but they varied among shrub litter treatments in both years (Supplementary Table S3). These differences were largely explained by species composition and its interaction with rain exclusion that affected both $H^{\prime}$ and $D$ after 1 year of decomposition (Table 1 ). After 2 years of decomposition, litter diversity effects were driven by species richness rather than composition (Table 1): $H^{\prime}$ increased (Fig. 1a) and D decreased (Fig. 1b) with increasing species richness in the litter mixtures. The plot-specific soil characteristics (Soil-PCA) also had a significant effect on $H^{\prime}$ and $D$ after 2 years of decomposition, which was of similar importance overall compared to litter species richness (Table 1). Finally, soil microbial indices from Pinus mesocosms showed no effect of rain exclusion, species composition, or species richness, nor of Soil-PCA (Table 1).
There was substantial variation in DCP, with the lowest rates measured in soils covered with pure Rosmarinus litter $(2.8 \pm 1.7 \%$ mass loss $)$ and the highest rates measured in soils covered with pure Cistus litter $(27.9 \pm 8.0 \%)$ after 1 year of decomposition. Rates of DCP varied somewhat less after 2 years, with the lowest rates measured in soils covered with the Rosmarinus/Ulex litter mixture $(25.6 \pm 7.3 \%)$ and the highest rates measured in soils covered with the four-species mixture Cistus/Quercus/Rosmarinus/Ulex (46.8 $\pm 7.5 \%$, Supplementary Table S3). After 1 year of decomposition, DCP rates were mainly explained by soil physicochemical parameters and to a lower extent by litter species composition (Table 1). None of the factors we evaluated had any significant effect on rates of DCP after 2 years of decomposition.

The observed litter composition effects on soil microbial parameters were in part related to the presence of particular litter species alone or in a mixture. For example, in the presence of Ulex litter, sum 15 after 2 years of decomposition was higher than when this species was absent (Table 2). Similarly, when Quercus litter was present, $H^{\prime}$ tended to be higher and $D$ to be lower after 2 years compared to when this species was absent (Table 2). The rate of DCP was constantly higher in the presence of Quercus leaf litter after 1 and 2 years of decomposition (Table 2) compared to litter treatments without any Quercus leaf litter. The presence of Rosmarinus litter had a negative effect both on sum15, but only after 1 year, and on DCP in both years (Table 2). The presence of Cistus litter had no effect on any of the microbial parameters in either year (Table 2). There were no interactions between the presence of a given species and the rain exclusion treatment.

\section{Effects of functional trait-based metrics on microbial substrate utilization}

For a more detailed understanding of how the identity and diversity of leaf litter decomposing at the soil surface affected the soil microbial parameters, we evaluated the relationships between litter mixture aggregated functional traits ( Trait $_{\mathrm{CWM}}$ ) or functional dissimilarity based on the Rao index (Trait ${ }_{\mathrm{FD}}$ ). We found no relationship between sum $15, H^{\prime}$, and $D$ of the soil microbial community with any of the aggregated traits of the litter mixtures in either year of sampling (Table 3). The only weak effect of aggregated litter traits was observed in the first year on DCP rates, which increased with increasing DOC $\mathrm{CWM}_{\mathrm{CW}}$ and with increasing $\mathrm{N}_{\mathrm{CWM}}$ (Table 3 and Fig. 2). Together, $\mathrm{DOC}_{\mathrm{CWM}}$ and $\mathrm{N}_{\mathrm{CWM}}$ accounted for $23 \%$ of the variance in DCP rates after 1 year of decomposition across all plots. However, these effects disappeared after 2 years of decomposition (Table 3) while the variation observed in the soil microbial parameters was more regularly associated to variation in soil characteristics (Soil-PCA, Table 3).

Soil-PCA accounted also for most of the variation in soil microbial parameters when assessing the impact of 
Table 1 Output of multiple linear models testing for the effects of rain exclusion treatment (RE), litter mixture species richness (richness), litter composition (COMP), and their interactions on the soil microbial

parameters (global metabolic activity (sum15), microbial metabolic diversity $\left(H^{\prime}\right)$, microbial metabolic dominance $(D)$, and rate of decomposition of cellulose paper (DCP))

\begin{tabular}{|c|c|c|c|c|c|c|c|c|}
\hline 2012 & & $d f$ & S.sq & M.sq & $F$ value & $p$ value & All $R^{2}$ (AIC) & MPM $R^{2}$ (AIC) \\
\hline \multirow[t]{2}{*}{ sum15 } & Soil-PCA & 1 & 0.085 & 0.085 & 3.261 & 0.074 & $0.17(-317.4)$ & $0.04(-333.8)$ \\
\hline & Residuals & 90 & 2.341 & 0.026 & & & & \\
\hline \multirow[t]{4}{*}{$H^{\prime}$} & $\mathrm{RE}$ & 1 & $1 \mathrm{e}-08$ & $1 \mathrm{e}-08$ & $2 \mathrm{e}-05$ & 0.997 & $0.49(-637.5)$ & $0.48(-638.44)$ \\
\hline & COMP & 14 & 0.022 & 0.002 & 2.102 & $0.024 *$ & & \\
\hline & $\mathbf{R E} \times \mathbf{C O M P}$ & 14 & 0.021 & 0.002 & 2.026 & $0.030 *$ & & \\
\hline & Residuals & 62 & 0.046 & 0.001 & & & & \\
\hline \multirow[t]{4}{*}{$D$} & $\mathrm{RE}$ & 1 & $2 \mathrm{e}-05$ & $1.6 \mathrm{e}-06$ & 0.011 & 0.915 & $0.47(-793)$ & $0.46(-793.6)$ \\
\hline & СОМР & 14 & 0.004 & $2.7 e-04$ & 1.967 & $0.036 *$ & & \\
\hline & $\mathrm{RE} \times \mathrm{COMP}$ & 14 & 0.003 & $2.5 \mathrm{e}-04$ & 1.785 & 0.061 & & \\
\hline & Residuals & 62 & 0.009 & $1.4 \mathrm{e}-04$ & & & & \\
\hline \multirow{3}{*}{ DCP } & Soil-PCA & 1 & 34.16 & 34.16 & 16.175 & $<0.001 * * *$ & $0.44(85.2)$ & $0.44(83.3)$ \\
\hline & COMP & 14 & 91.01 & 6.50 & 3.078 & $<0.001 * * *$ & & \\
\hline & Residuals & 76 & 160.52 & 2.11 & & & & \\
\hline \multicolumn{9}{|l|}{2013} \\
\hline \multirow[t]{3}{*}{ sum15 } & Soil-PCA & 1 & 0.260 & 0.260 & 14.467 & $<0.001 * * *$ & $0.36(-353.3)$ & $0.36(-355.3)$ \\
\hline & COMP & 14 & 0.508 & 0.036 & 2.022 & $0.027 *$ & & \\
\hline & Residuals & 76 & 1.364 & 0.018 & & & & \\
\hline \multirow[t]{3}{*}{$H^{\prime}$} & Soil-PCA & 1 & 0.001 & 0.001 & 7.800 & $0.006 * *$ & $0.29(-786.9)$ & $0.14(-797.2)$ \\
\hline & richness & 1 & 0.001 & 0.001 & 6.864 & $0.01 * \uparrow$ & & \\
\hline & Residuals & 89 & 0.015 & 0.0002 & & & & \\
\hline \multirow[t]{3}{*}{$D$} & Soil-PCA & 1 & 0.0001 & $1.5 \mathrm{e}-04$ & 6.152 & $0.015^{*}$ & $0.26(-960.3)$ & $0.13(-972.5)$ \\
\hline & richness & 1 & 0.0002 & $1.7 e-04$ & 6.808 & $0.01 * \downarrow$ & & \\
\hline & Residuals & 89 & 0.002 & $2.5 \mathrm{e}-05$ & & & & \\
\hline DCP & Intercept & & & & & & 0.16 & \\
\hline \multicolumn{9}{|l|}{ Pinus litters } \\
\hline \multirow[t]{2}{*}{ sum15 } & Soil-PCA & 1 & 0.227 & 0.227 & 10.34 & $0.002 * *$ & $0.36(-322.7)$ & $0.10(-349.6)$ \\
\hline & Residuals & 90 & 1.971 & 0.022 & & & & \\
\hline \multirow[t]{2}{*}{$H^{\prime}$} & Soil-PCA & 1 & 0.0009 & 0.0009 & 2.34 & 0.13 & $0.37(-696.7)$ & $0.03(-714.1)$ \\
\hline & Residuals & 90 & 0.038 & 0.0004 & & & & \\
\hline$D$ & Intercept & & & & & & 0.35 & \\
\hline
\end{tabular}

Plot-specific soil characteristics (Soil-PCA) were included as co-variable. We report the $R^{2}$ and AIC weight of the general model including all factors (All) and of the most parsimonious model (MPM, in bold). Only the variables retained in the most parsimonious models are reported (intercept $=$ none of variable was retained). $d f=$ the degrees of freedom, $\mathrm{S} . \mathrm{sq}=$ the sum of squares, M. sq = the mean square. $n=92$ plots in 2012, 2013, and for pine litters, respectively. Arrows indicate the direction of the effect

$p<0.10 ; * p<0.05 ; * * p<0.01 ; * * * p<0.001, F$ value and associated significance of $p$ value (in bold when $p<0.05$ )

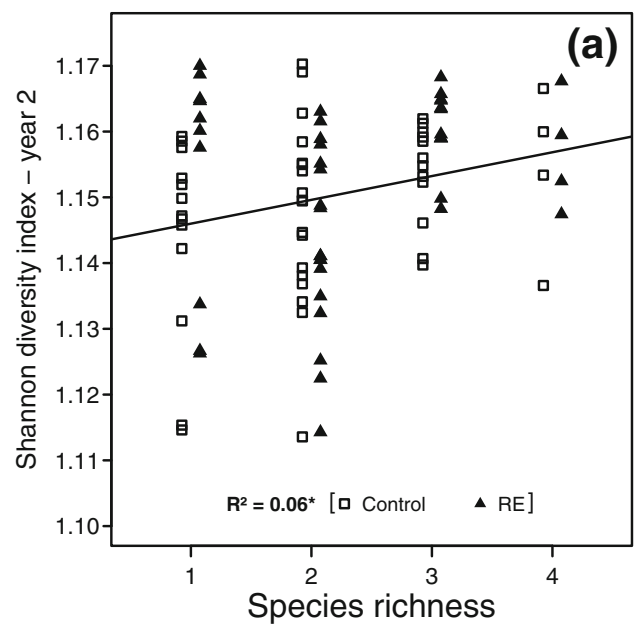

Fig. 1 Relationships between species richness in the litter mixtures and soil microbial metabolic diversity (Shannon diversity index) (a) or soil microbial metabolic dominance (Simpson dominance index) (b) after 2 years. Open symbols are for control plots and close symbols are for

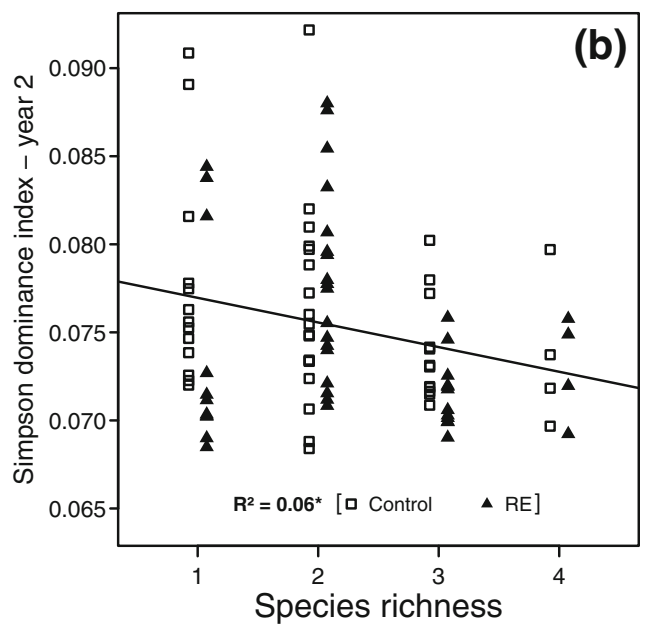

rain excluded plots. $R^{2}$ (with associated significance of $p$ value, $* p<0.05)$ and solid lines are the linear regressions across all plots $(n=92)$ 
Table 2 Output of multiple linear models testing for the effect of rain exclusion treatment (RE) and presence of the different individual litter species (Cistus, Quercus, Rosmarinus, and Ulex) in the litter mixture and their interactions with RE on microbial parameters (global metabolic activity (sum15), microbial metabolic diversity $\left(H^{\prime}\right)$, microbial metabolic dominance $(D)$, and rate of decomposition of cellulose paper (DCP))

\begin{tabular}{|c|c|c|c|c|c|c|c|c|}
\hline & \multicolumn{2}{|l|}{ sum15 } & \multicolumn{2}{|l|}{$H^{\prime}$} & \multicolumn{2}{|l|}{$D$} & \multicolumn{2}{|l|}{ DCP } \\
\hline & 2012 & 2013 & 2012 & 2013 & 2012 & 2013 & 2012 & 2013 \\
\hline Soil-PCA & $N S$ & $12.902 * * *$ & $4.388 *$ & $7.515 * *$ & $5.106 *$ & $5.945^{*}$ & $13.648 * * *$ & $N S$ \\
\hline $\mathrm{RE}$ & $N S$ & $N S$ & $N S$ & $N S$ & $N S$ & $N S$ & $N S$ & $N S$ \\
\hline Quercus & $N S$ & $N S$ & $N S$ & $3.366 \uparrow$ & $N S$ & $3.586 \downarrow$ & $5.437 * \uparrow$ & $2.763 \uparrow$ \\
\hline Cistus & $N S$ & $N S$ & $N S$ & $N S$ & $N S$ & $N S$ & $N S$ & $N S$ \\
\hline Ulex & $N S$ & $4.026^{*} \uparrow$ & $N S$ & $N S$ & $N S$ & $N S$ & $N S$ & $N S$ \\
\hline Rosmarinus & $4.965^{*} \downarrow$ & $N S$ & $N S$ & $N S$ & $N S$ & $N S$ & $7.041 * * \downarrow$ & $2.881 \downarrow$ \\
\hline
\end{tabular}

Plot-specific soil characteristics (Soil-PCA) were included as co-variable. Only the variables retained in the most parsimonious models are reported. $n=92$ plots in 2012 and 2013, respectively. Arrows indicate the direction of the effect. Interactions between individual litter species and RE were never significant and are not reported

NS not significant effect

$p<0.10 ; * p<0.05 ; * *<<0.01 ; * * * p<0.001, F$ value and associated significance of $p$ value

functional dissimilarity of traits in litter mixtures. However, functional trait dissimilarity appeared to be generally more important for soil microbial parameters compared to CWM traits, in particular after 2 years of decomposition (Table 4). After 2 years, sum 15 increased with increasing Lignin $_{\mathrm{FD}}$ (Table 4 and Fig. 3a), and $H^{\prime}$ increased and $D$ decreased with increasing Phenolics $\mathrm{FD}$ in the litter mixtures (Table 4 and Fig. 3c, d). Rates of DCP showed a marginally significant increase with increasing Phenolics $\mathrm{FD}$ (Table 4). After 1 year, there was
Table 3 Outputs of multiple linear models testing for the effects of aggregated traits $\left(\right.$ trait $_{\mathrm{CWM}}$ ) in litter mixture, rain exclusion treatment $(\mathrm{RE})$, and their interactions on soil microbial parameters (global metabolic activity (sum15), microbial metabolic diversity $\left(H^{\prime}\right)$, microbial metabolic dominance $(D)$, and rate of decomposition of cellulose paper (DCP))

\begin{tabular}{|c|c|c|c|c|c|c|c|c|}
\hline 2012 & & $d f$ & S.sq & M.sq & $F$ value & $p$ value & All $R^{2}$ (AIC) & $\operatorname{MPM} R^{2}(\mathrm{AIC})$ \\
\hline sum15 & $\begin{array}{l}\text { Soil-PCA } \\
\text { Residuals }\end{array}$ & $\begin{array}{l}1 \\
90\end{array}$ & $\begin{array}{l}0.085 \\
2.341\end{array}$ & $\begin{array}{l}0.085 \\
0.026\end{array}$ & 3.261 & 0.074 & $0.05(-327.4)$ & $0.04(-333.8)$ \\
\hline$H^{\prime}$ & $\begin{array}{l}\text { Soil-PCA } \\
\text { Residuals }\end{array}$ & $\begin{array}{l}\mathbf{1} \\
90\end{array}$ & $\begin{array}{l}\mathbf{0 . 0 0 4} \\
0.086\end{array}$ & $\begin{array}{l}\text { 0.004 } \\
9 \mathrm{e}-04\end{array}$ & 4.388 & $0.039 *$ & $0.05(-630.6)$ & $0.05(-638.4)$ \\
\hline$D$ & $\begin{array}{l}\text { Soil-PCA } \\
\text { Residuals }\end{array}$ & $\begin{array}{l}1 \\
90\end{array}$ & $\begin{array}{l}\text { 9e-04 } \\
0.015\end{array}$ & $\begin{array}{l}9 e-04 \\
2 \mathrm{e}-04\end{array}$ & 5.106 & $0.026 *$ & $0.06(-790.3)$ & $0.05(-798.4)$ \\
\hline DCP & $\begin{array}{l}\text { Soil-PCA } \\
\text { DOC }_{C W M}\end{array}$ & $\begin{array}{l}1 \\
1\end{array}$ & $\begin{array}{l}34.16 \\
19.32\end{array}$ & $\begin{array}{l}34.16 \\
19.32\end{array}$ & $\begin{array}{l}14.328 \\
8.104 \uparrow\end{array}$ & $\begin{array}{l}<0.001 * * * * \\
0.006 * *\end{array}$ & $0.27(87.2)$ & $0.27(84.0)$ \\
\hline & $\begin{array}{l}\mathbf{N}_{\mathbf{C W M}} \\
\text { Residuals }\end{array}$ & $\begin{array}{l}1 \\
88\end{array}$ & $\begin{array}{l}\mathbf{2 2 . 3 7} \\
209.84\end{array}$ & $\begin{array}{l}\mathbf{2 2 . 3 7} \\
2.38\end{array}$ & $9.380 \uparrow$ & $0.003 * *$ & & \\
\hline 2013 & & & & & & & & \\
\hline sum15 & $\begin{array}{l}\text { Soil-PCA } \\
\text { Residuals }\end{array}$ & $\begin{array}{l}\mathbf{1} \\
90\end{array}$ & $\begin{array}{l}\mathbf{0 . 2 6 0} \\
1.872\end{array}$ & $\begin{array}{l}\mathbf{0 . 2 6 0} \\
0.021\end{array}$ & 12.48 & $<0.001 * * *$ & $0.15(-349.6)$ & $0.14(-354.5)$ \\
\hline$H^{\prime}$ & $\begin{array}{l}\text { Soil-PCA } \\
\text { Residuals }\end{array}$ & $\begin{array}{l}\mathbf{1} \\
90\end{array}$ & $\begin{array}{l}\mathbf{0 . 0 0 1} \\
0.016\end{array}$ & $\begin{array}{l}\mathbf{0 . 0 0 1} \\
2 \mathrm{e}-04\end{array}$ & 7.323 & $0.008 * *$ & $0.09(-785.7)$ & $0.08(-792.3)$ \\
\hline$D$ & $\begin{array}{l}\text { Soil-PCA } \\
\text { Residuals }\end{array}$ & $\begin{array}{l}\mathbf{1} \\
90\end{array}$ & $\begin{array}{l}\mathbf{2 e - 0 4} \\
0.002\end{array}$ & $\begin{array}{l}\mathbf{1 . 5 e - 0 4} \\
2.6 \mathrm{e}-05\end{array}$ & 5.779 & $0.018^{*}$ & $0.07(-961.0)$ & $0.06(-967.8)$ \\
\hline DCP & Intercept & & & & & & 0.06 & \\
\hline
\end{tabular}

Plot-specific soil characteristics (Soil-PCA) were included as co-variable. Interactions between trait ${ }_{\text {CWM }}$ and RE treatment were never significant. Only the variables retained in the most parsimonious models are reported (intercept $=$ none of variable was retained). We report the $R^{2}$ and AIC weight of the general model including all factors (All) and of the most parsimonious model (MPM, in bold). $d f=$ the degrees of freedom, S.sq $=$ the sum of squares, M. sq $=$ the mean square. $n=92$ plots in 2012 and 2013, respectively. Arrows indicate the direction of the effect $p<0.10 ; * p<0.05 ; * * p<0.01 ; * * * p<0.001, F$ value and associated significance of $p$ value (in bold when $p<0.05$ ) 


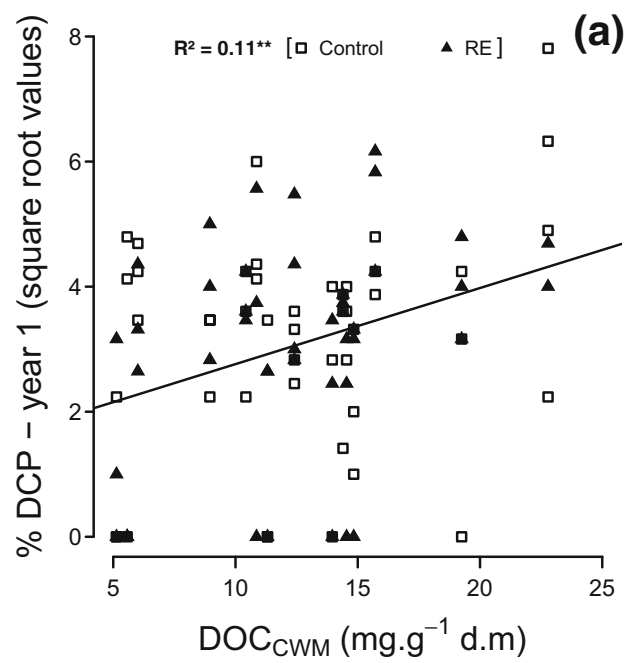

Fig. 2 Relationship between DCP rates and community weighted mean traits of litter mixtures for dissolved organic $\mathrm{C}\left(\mathrm{DOC}_{\mathrm{CWM}}\right)$ (a) or for total $\mathrm{N}\left(\mathrm{N}_{\mathrm{CWM}}\right)$ (b) after 1 year. Open symbols are for control plots and close

an additional negative effect of increasing $\mathrm{WHC}_{\mathrm{FD}}$ on rates of DCP (Table 4 and Fig. 3b). Finally, interactions between individual Trait $_{\mathrm{CWM}}$ or Trait $_{\mathrm{FD}}$ and rain

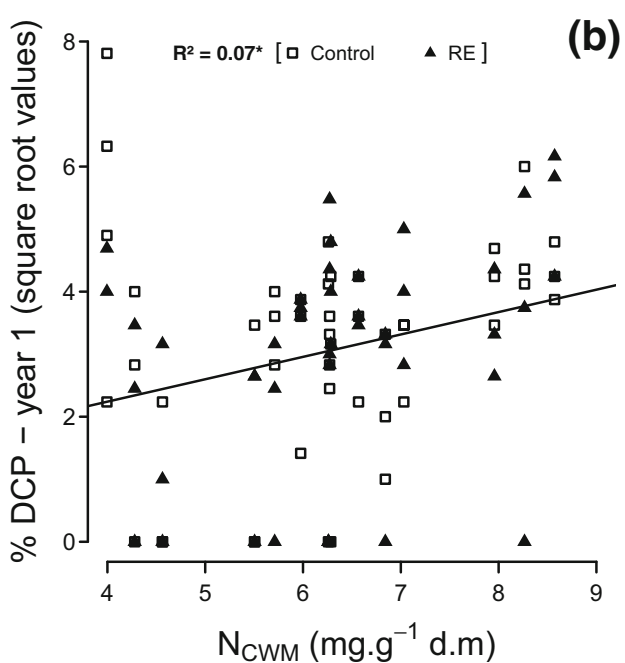

symbols are for rain excluded plots. $R^{2}$ (with associated significance of $p$ value: $* p<0.05, * * p<0.01)$ and solid lines are the linear regressions across all plots $(n=92)$

exclusion were never significant, indicating that the reported effects did not depend on the amount of rainfall received.
Table 4 Output of multiple linear models testing for the effects of functional diversity of litter mixtures ( trait $_{\mathrm{FD}}$ ), rain exclusion treatment $(\mathrm{RE})$, and their interactions on soil microbial parameters (global metabolic activity (sum15), microbial metabolic diversity $\left(H^{\prime}\right)$, microbial metabolic dominance $(D)$, and rate of decomposition of cellulose paper (DCP))

\begin{tabular}{|c|c|c|c|c|c|c|c|c|}
\hline 2012 & & $d f$ & S.sq & M.sq & $F$ value & $p$ value & All $R^{2}$ (AIC) & MPM $R^{2}$ (AIC) \\
\hline sum15 & $\begin{array}{l}\text { Soil-PCA } \\
\text { Residuals }\end{array}$ & $\begin{array}{l}1 \\
90\end{array}$ & $\begin{array}{l}0.085 \\
2.341\end{array}$ & $\begin{array}{l}0.085 \\
0.026\end{array}$ & 3.261 & 0.074 & $0.10(-329.9)$ & $0.04(-333.8)$ \\
\hline$H^{\prime}$ & $\begin{array}{l}\text { Soil-PCA } \\
\text { Residuals }\end{array}$ & $\begin{array}{l}1 \\
90\end{array}$ & $\begin{array}{l}\mathbf{0 . 0 0 4} \\
0.086\end{array}$ & $\begin{array}{l}\text { 0.004 } \\
9 \mathrm{e}-04\end{array}$ & 4.388 & $0.039 *$ & $0.07(-630.2)$ & $0.05(-638.2)$ \\
\hline$D$ & $\begin{array}{l}\text { Soil-PCA } \\
\text { Residuals }\end{array}$ & $\begin{array}{l}\mathbf{1} \\
90\end{array}$ & $\begin{array}{l}\mathbf{9 e - 0 4} \\
0.015\end{array}$ & $\begin{array}{l}\mathbf{9 e - 0 4} \\
2 \mathrm{e}-04\end{array}$ & 5.106 & $0.026 *$ & $0.08(-790)$ & $0.05(-798.2)$ \\
\hline $\mathrm{DCP}$ & $\begin{array}{l}\text { Soil-PCA } \\
\text { WHC }_{\text {FD }} \\
\text { Residuals }\end{array}$ & $\begin{array}{l}\mathbf{1} \\
\mathbf{1} \\
89\end{array}$ & $\begin{array}{l}\mathbf{3 4 . 1 6} \\
\mathbf{1 5 . 2 2} \\
236.31\end{array}$ & $\begin{array}{l}34.16 \\
15.22 \\
2.66\end{array}$ & $\begin{array}{l}12.867 \\
5.731 \downarrow\end{array}$ & $\begin{array}{l}<0.001 * * * \\
0.019 *\end{array}$ & $0.20(97.7)$ & $0.17(92.8)$ \\
\hline 2013 & & & & & & & & \\
\hline sum15 & $\begin{array}{l}\text { Soil-PCA } \\
\text { Lignin }_{\text {FD }} \\
\text { Residuals }\end{array}$ & $\begin{array}{l}\mathbf{1} \\
\mathbf{1} \\
89\end{array}$ & $\begin{array}{l}\mathbf{0 . 2 6 0} \\
\mathbf{0 . 2 2 0} \\
1.65\end{array}$ & $\begin{array}{l}\mathbf{0 . 2 6 0} \\
\mathbf{0 . 2 2 0} \\
0.019\end{array}$ & $\begin{array}{l}13.99 \\
11.84 \uparrow\end{array}$ & $\begin{array}{l}0.0003 * * * \\
<0.001 * * *\end{array}$ & $0.28(-362.7)$ & $0.23(-366.7)$ \\
\hline$H^{\prime}$ & $\begin{array}{l}\text { Soil-PCA } \\
\text { Phenolics }_{\text {FD }} \\
\text { Residuals }\end{array}$ & $\begin{array}{l}\mathbf{1} \\
\mathbf{1} \\
89\end{array}$ & $\begin{array}{l}\mathbf{0 . 0 0 1} \\
\mathbf{9 e - 0 4} \\
0.015\end{array}$ & $\begin{array}{l}0.001 \\
9 e-04 \\
2 e-04\end{array}$ & $\begin{array}{l}7.679 \\
5.376 \uparrow\end{array}$ & $\begin{array}{l}0.0068 * * \\
0.0227^{*}\end{array}$ & $0.18(-792.9)$ & $0.13(-795.8)$ \\
\hline$D$ & $\begin{array}{l}\text { Soil-PCA } \\
\text { PhenolicsFD } \\
\text { Residuals }\end{array}$ & $\begin{array}{l}\mathbf{1} \\
\mathbf{1} \\
89\end{array}$ & $\begin{array}{l}2 \mathrm{e}-04 \\
1 \mathrm{e}-04 \\
0.002\end{array}$ & $\begin{array}{l}1.5 e-04 \\
1.3 e-04 \\
2.5 e-05\end{array}$ & $\begin{array}{l}6.035 \\
4.980 \downarrow\end{array}$ & $\begin{array}{l}0.0160 * \\
0.0281 *\end{array}$ & $0.16(-967.8)$ & $0.11(-970.9)$ \\
\hline DCP & $\begin{array}{l}\text { Phenolics } \\
\text { RD } \\
\text { Residuals }\end{array}$ & $\begin{array}{l}1 \\
90\end{array}$ & $\begin{array}{l}5.06 \\
154.66\end{array}$ & $\begin{array}{l}5.061 \\
1.718\end{array}$ & $2.945 \uparrow$ & 0.0896 & $0.09(56.2)$ & $0.03(52.5)$ \\
\hline
\end{tabular}

Plot-specific soil characteristics (Soil-PCA) were included as co-variable. Interactions between trait ${ }_{\mathrm{FD}}$ and RE treatment were never significant. We report the $R^{2}$ and AIC weight of the general model including all factors (All) and of the most parsimonious model (MPM, in bold). Only the variables retained in the most parsimonious models are reported. $d f=$ the degrees of freedom, $\mathrm{S} . \mathrm{sq}=$ the sum of squares, M. sq $=$ the mean square. $n=92$ plots in 2012 and 2013, respectively. Arrows indicate the direction of the effect

$p<0.10 ; * p<0.05 ; * * p<0.01 ; * * * p<0.001, F$ value and associated significance of $p$ value (in bold when $p<0.05$ ) 

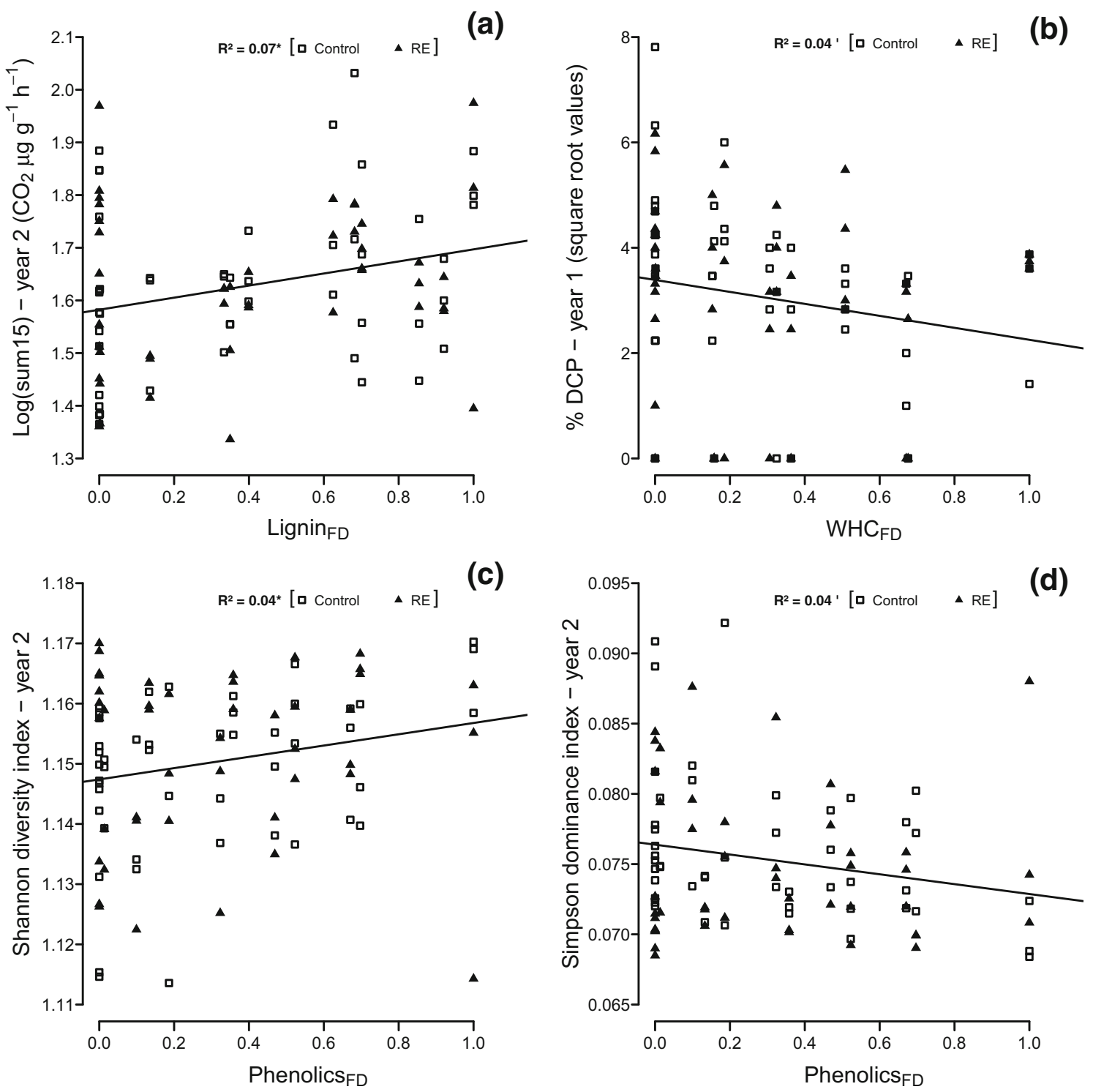

Fig. 3 Relationships between soil microbial metabolic parameters and functional dissimilarity of litter traits in the litter mixtures (a) between sum 15 and Lignin ${ }_{\mathrm{FD}}$ after 2 years, (b) between cellulose decomposition rates $(\mathrm{DCP})$ and $\mathrm{WHC}_{\mathrm{FD}}$ after 1 year, and $(\mathbf{c}, \mathbf{d})$ between $H^{\prime}$ or $D$ index,

\section{Path analysis testing links between species richness, $H^{\prime}$, and sum 15}

As $H^{\prime}$ correlated with sum15 $\left(R^{2}=0.36\right)$ (Fig. 4a) and species richness significantly affected $H^{\prime}$ after 2 years (Table 1 ), we used path analysis to test the emerging conjecture that species richness affects sum 15 via an indirect pathway from $H^{\prime}$ to sum15. The model converged $\left(\chi^{2}=0.03, p=0.83\right)$ and showed a very good model fit (RMSEA $=0, \mathrm{CFI}=1$, $\left.\mathrm{AIC}_{\text {model }}=14.97, \mathrm{AIC}_{\text {unrestricted model }}=16.94\right)$. The path diagram of the model (Fig. 4b) displays a significant pathway between litter species richness and $H^{\prime}$ (standardized regression weight $=0.26, p<0.01$ ).

respectively, and Phenolics $\mathrm{FD}_{\mathrm{F}}$ after 2 years. Open symbols are for control plots and closed symbols are for rain excluded plots. $R^{2}$ (with associated significance of $p$ value: $p<0.10, * p<0.05)$ and solid lines are the linear regressions across all plots $(n=92)$

\section{Discussion}

In this study, we used a natural diversity gradient with four Mediterranean shrub species to address the question how a combined change in diversity of plants litter input and a reduction in precipitation affect the functioning of the soil microbial community.

Our results showed that the measured soil microbial parameters (that were based on how microbial communities utilize a range of different $\mathrm{C}$ substrates) depended on the soil physicochemical properties, with a particular strong effect after 2 years, in line with previously reported soil characteristics effects (see for instance Delmont et al. 2014). On the other 
(a)

(b)
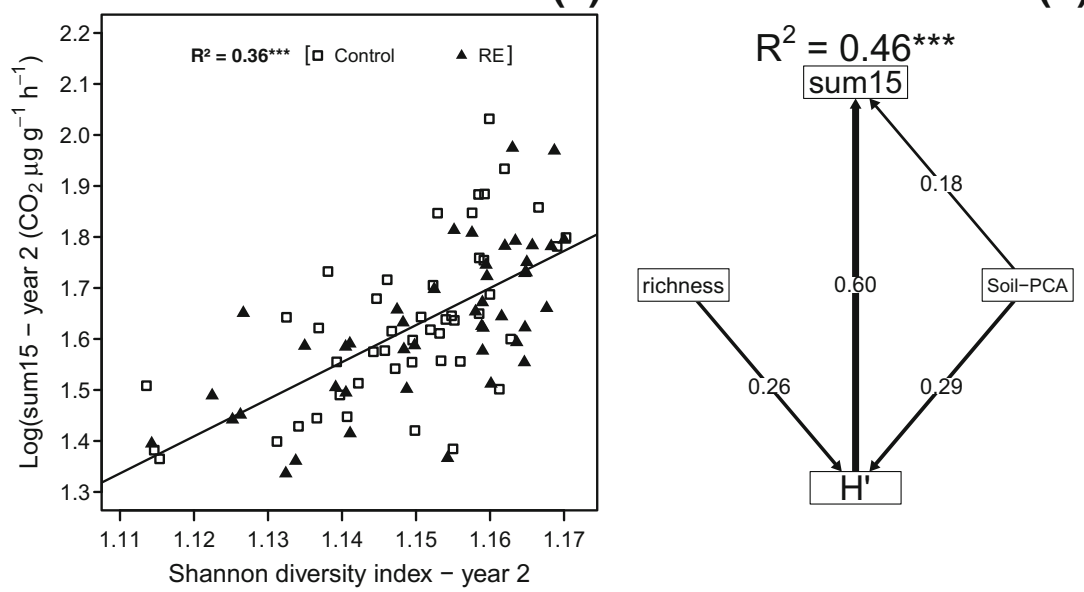

Fig. 4 a Relationships between the global metabolic activity (sum15) and the Shannon soil microbial metabolic diversity index $\left(H^{\prime}\right)$ after 2 years. The solid line is the linear regression across all plots $(n=92)$. b Path analysis showing the supported causal links between leaf litter species richness, the soil microbial metabolic diversity $\left(H^{\prime}\right)$, the global

soil microbial metabolic activity (sum15), and the soil characteristics (Soil-PCA) after 2 years. Arrows indicate significant relationships. Numbers on the arrows show standardized regression weights. All paths are significant at $p \leq 0.01$ except the Soil-PCA to sum 15 pathway $(p=0.022)$

hand, soil microbial parameters were generally not affected by the moderate rain exclusion we applied (see Fig. S3 and associated comment for more details). Accordingly, but in contrast to our initial hypothesis stating that microbial communities underneath higher diverse litter mixtures are less affected by reduced precipitation, there were no interactive effects between rain exclusion and litter diversity measures on microbial parameters. The sole exception was that litter species composition distinctly affected the microbial $H^{\prime}$ and $D$ in control compared to rain-excluded plots after 1 year of field exposure of litter. This comparatively short-term response, which did not persist into the second year, suggests that the soil microbial communities associated to different litter mixtures responded differently to rain exclusion during the initial stage of decomposition. Because litter leaching is an important process early in the decomposition dynamics (Swift et al. 1979; Berg and Laskowski 2005), the interaction between litter composition and the amount of precipitation in the first year of the experiment may result from less leachate transfer to the soil with partial rain exclusion in some litter combinations. However, in our further tests evaluating the effects of species presence or of mean trait values of the litter mixtures, we could not relate this response to the presence of a particular shrub species or to a particular litter trait (Tables 2 and 3). The relatively moderate rain exclusion applied in our study that resulted in a $6.5 \%$ lower soil water content on average in rain-excluded plots compared to the control plots might not have been strong enough to affect the functioning of the soil microbial communities more clearly and more consistently over the 2 years of our experiment. On the other hand, previous studies applying more severe treatments of rain exclusion and evaluating the effect on soil processes in Mediterranean ecosystems also reported weak or no effects

(Sardans et al. 2006; de Dato et al. 2010; Pailler et al. 2014). For example, de Dato et al. (2010) applied a total rain exclusion during spring and autumn in a semiarid Mediterranean shrubland and reported decreased soil $\mathrm{CO}_{2}$ emissions for only three of ten occasions in rain-excluded plots compared to control plots after 5 years of climate manipulation. Pailler et al. (2014) showed that a severe heat-drought stress applied on soil samples from a Mediterranean forest $\left(10\right.$ days at $\left.50{ }^{\circ} \mathrm{C}\right)$ decreased the activity of the soil microbial community but did not affect their catabolic profiles, compared to control conditions. No effect of summer drought on soil community catabolic profiles was reported by Sardans et al. (2006) and de Dato et al. (2010). In another experiment assessing the effect of multiple drying-rewetting cycles on surface and subsurface soils from a California annual grassland soil, Xiang et al. (2008) reported that microbial biomass and activity were not or only moderately affected by wetting and drying cycles. Collectively, these results suggest that because microbial communities in drought-affected ecosystems evolved and adapted to periodic drought, they may represent a considerable resistance to interannual variations in soil water availability. However, consistently lower precipitation over a longer time period may affect the adaptive trajectory of microbial communities that has not yet been detected in the relatively short-term studies cited above, including our own. In fact, in a long-term experiment excluding $29 \%$ of rainfall over 11 years, GarcíaPalacios et al. (2016) reported negative effects on soil microbial biomass and altered substrate utilization patterns in a soil under Mediterranean holm oak forest, indicating that soil microbial functioning may well change in response to long-term changes in soil water availability.

We predicted with our first hypothesis that increasing diversity of leaf litter decomposing at the soil surface would 
increase the capacity of soil microbial communities to metabolize diverse substrates and therefore lead to an increased overall microbial activity. The different litter treatments representing the plot-specific woody shrub composition indeed led to altered microbial metabolic diversity, dominance indices, and DCP rates after the litter had been decomposed for 1 year. This litter composition effect, however, was overall relatively weak (Table 1). Species composition effects on ecosystem processes could be driven by the presence of specific species and the physical and chemical traits they represent. In our study, DCP rates consistently increased with the presence of Quercus litter and decreased with that of Rosmarinus. Also, the presence of Ulex litter increased sum 15 and $H^{\prime}$, while that of Rosmarinus decreased $H^{\prime}$ (Table 2). The negative effect of Rosmarinus may be related to inhibiting compounds produced by this species (Gómez-Aparicio et al. 2004), and the positive effects of Quercus and Ulex may be associated to their relatively high $\mathrm{N}$ concentrations (in comparison to Cistus and Rosmarinus). In fact, DCP rates measured after 1 year increased with increasing $\mathrm{N}$ concentrations in the litter mixtures $\left(\mathrm{N}_{\mathrm{CWM}}\right.$, Table 3). This $\mathrm{N}$ effect and a DOC effect on DCP were the only significant effects of community-weighted mean traits we observed, but they disappeared in the second year, probably once DOC and soluble $\mathrm{N}$ are leached from decomposing litter. This transient effect of DOC on soil microorganisms is in line with a recent study that reported that leaf litter leachates induced rapid increase in soil microbial respiration and shift in community composition, that were positively associated with soluble $\mathrm{C}$ and $\mathrm{N}$ concentrations (Joly et al. 2016). In contrast, soil microbial metabolic parameters were better explained by functional dissimilarity of litter traits, especially after 2 years. This finding supports our initial hypothesis that increasingly dissimilar litter substrates provide a greater spectrum of resources fostering complementary resource use by soil microorganisms. The soil microbial metabolic activity increased with increasing Lignin ${ }_{\mathrm{FD}}$, while $H^{\prime}$ and DCP (only marginally significant) rates increased, and $D$ decreased with increasing Phenolics $\mathrm{FD}_{\mathrm{FD}}$. These results indicate that a high dissimilarity in $\mathrm{C}$ compounds within litter mixtures has a particularly important role for microbial metabolic diversity and substrate use efficiency. Higher soil microbial activity with increasing litter lignin content is rather unexpected since this compound is recalcitrant, but this could result from the stimulation of lignin-degrading enzymes in the soil following long-term inputs of lignin-rich litter substrates in the corresponding plots. The relatively important role of Phenolics $\mathrm{FD}_{\mathrm{FD}}$ was not surprising since phenolic compounds can directly affect the composition and activity of soil organisms (Schimel et al. 1998; Hättenschwiler and Vitousek 2000; Coq et al. 2010; Chen et al. 2015). The observed decrease in $D$ and the concomitant increase in $H^{\prime}$ with increased dissimilarity of phenolics in litter mixtures indicate that litter mixtures containing species with distinct phenolics composition promote a metabolically more diverse microbial community because of more diverse $\mathrm{C}$ substrates.

In contrast to the litter species composition effect that disappeared with ongoing decomposition but in line with increasing relative importance of trait dissimilarity vs. communityweighted mean traits discussed above, the species richness effect apparently got stronger and was positively related to $H^{\prime}$ and negatively related to $D$ after 2 years of decomposition in the field (Fig. 1). Field studies explicitly addressing the question how surface litter influence the functioning of microbial communities in the underlying soil are rare in general and in particular for the evaluation of litter diversity effects. A previous study in a tree species-rich tropical rainforest showed that up to $50 \%$ of the variability in soil microbial respiration was accounted for by the quality of decomposing leaf litter at the soil surface (Fanin et al. 2011). Also, in an incubation experiment using mixed litter from alpine steppe species, Chen et al. (2015) found that plant species richness affected soil $\mathrm{N}$ and $\mathrm{C}$ dynamics (in particular the cumulative soil $\mathrm{CO}_{2}$ emission) but to a lower extent compared to the chemical traits of litter. Here, we showed that an increasing number of plant litter species increased the metabolic diversity of soil microbial communities. According to our path analysis, the plant richness-related increase in microbial metabolic diversity was then the major driver of the higher global soil microbial activity. In fact, $H^{\prime}$ accounted for a higher amount of variability observed in sum15 than the soil parameters (Fig. 4b) that varied greatly among plots. These findings strongly suggest that higher plant species richness increases metabolic diversity of soil microbial communities via an increased resource diversity that ultimately stimulates microbial activity. Total activity and metabolic diversity of soil microbial communities therefore would not solely be a characteristic of microbial diversity but would depend also on the diversity of substrates provided by the plants in contrast to the theoretical model proposed by Loreau (2001). Similarly, Fonte et al. (2013) reported a higher biomass production and growth efficiency of aquatic bacterial communities provided with a mixture of different $\mathrm{C}$ compounds compared to single $\mathrm{C}$ compounds, with only a minor role of bacterial community composition. Plant species richness effects on soil microbial communities and the processes they drive have been reported in grassland diversity experiments before (Reich et al. 2001; Chung et al. 2007; Eisenhauer et al. 2010, 2013). For instance, in the Jena Biodiversity experiment, Lange et al. (2015) showed that soil microbial activity in temperate grassland increased underneath plant communities with higher species richness, which they interpreted as a result of higher rhizosphere $\mathrm{C}$ input in more diverse compared to less diverse plant communities. However, the underlying mechanisms of how higher plant species richness is affecting the various components of the soil microbial communities (e.g., biomass, activity, functional diversity) are yet to be demonstrated. It is difficult to separate living plant 
effects from plant litter effects, especially in a field experiment with continuous long-term inputs of litter material and welldeveloped root systems. In our study, the exposed litter mixtures represented the plot-specific plant composition, and the reported effects may be a combination of root and decomposing litter effects. There are two lines of evidence suggesting that the species richness effects we observed are primarily a consequence of litter decomposing at the soil surface. First, species richness had no influence in the first year. If root processes would be the dominant factor, the relationship between plant richness and microbial parameters should have been similar in both years. However, our results showed that the relationship was only detectable in the second year, suggesting that with ongoing decomposition and progressive transfer of decomposition products to the underlying soil, decomposing surface litter was probably a more determinant plant richness effect than root processes. Second, there were no plant diversity effects on microbial parameters in soils underneath the common leaf litter from $P$. halepensis, which we exposed in all plots in addition to the plot-specific litter. Again, if root processes would dominate the responses of soil microbial communities, the effect of plant richness after 2 years should have been similar independently of the identity of litter decomposing at the soil surface. Hence, our results suggest that plant diversity can exhibit an important control over soil microbial functioning through the input of surface litter and the associated diversity of organic resources.

We conclude that the microbial activity and their capacity to use a range of different substrates were little affected by the moderate rain exclusion we applied to the studied Mediterranean shrubland. Such weak effects are probably the result of an only small change in soil humidity. Also, the soil microbial community in the studied Mediterranean ecosystem is adapted to recurrent drought stress and may only change after several years of modifications in the precipitation regime. In contrast, the composition, species richness, and functional diversity of the shrub community had a clear effect on the microbial parameters we assessed here. There was some striking evidence that the reported plant diversity effects on soil microbial communities are driven by leaf litter decomposing on the soil surface rather than mediated by plant root systems. In line with a previous study (Lloret et al. 2015), our results suggest that climate change effects on plant species composition and richness might have more important consequences for soil microbial functioning than reduced precipitation in the studied Mediterranean shrubland ecosystems. However, the relative impact of direct and indirect climate change-driven consequences will depend on the magnitude of change and the temporal scale considered.
Acknowledgements We are grateful to all the colleagues from CEFE UMR 5175 and from IMBE UMR 7263 who contributed to the setup and maintenance of the rain exclusion experiment in Marseille. Litter C, N, P, phenolic, and WHC analyses were performed at the IMBE UMR 7263 in Marseille with the help of Caroline Lecareux. DCP and MicroResp analyses were performed at the Plate-Forme d'Analyses Chimiques en Ecologie, LabEx Centre Méditerranéen de l'Environnement et de la Biodiversité. Dissolved carbon and nitrogen analyses were performed at the Eco\&Sols BioSolTrop lab (LabEx Centre Méditerranéen de l'Environnement et de la Biodiversité) in Montpellier with the help of Jean Larvy Delarivière. We are grateful to Dr. Paolo Nannipieri and two anonymous reviewers for their comments that helped to improve the manuscript. Funding was provided by the Agence Nationale de la Recherche (contract "ANR-09-CEPL-007") through the project CLIMED. A. Shihan received a PhD grant from the Syrian Ministry of Higher Education, University of Aleppo.

\section{References}

Ayres E, Steltzer H, Simmons BL, Simspon RT, Steinweg JM, Wallenstein MD, Mellor N, Parton WJ, Mooe JC, Wall DH (2009) Home-field advantage accelerates leaf litter decomposition in forests. Soil Biol Biochem 41:606-610. doi:10.1016/j. soilbio.2008.12.022

Ball BA, Hunter MD, Kominoski JS, Swan CM, Bradford MA (2008) Consequences of non-random species loss for decomposition dynamics: experimental evidence for additive and non-additive effects. J Ecol 96:303-313. doi:10.1111/j.1365-2745.2007.01346.x

Barantal S, Roy J, Fromin N, Schimann H, Hättenschwiler S (2011) Long-term presence of tree species but not chemical diversity affect litter mixture effects on decomposition in a neotropical rainforest. Oecologia 167:241-252. doi:10.1007/s00442-011-1966-4

Barantal S, Schimann H, Fromin N, Hättenschwiler S (2014) C, N and P fertilization in an Amazonian rainforest supports stoichiometric dissimilarity as a driver of litter diversity effects on decomposition. Proc Biol Sci 281:20141682. doi:10.1098/rspb.2014.1682

Bérard A, Sassi MB, Renault P, Gros R (2012) Severe drought-induced community tolerance to heat wave. An experimental study on soil microbial processes. J Soils Sediments 12:513-518. doi:10.1007 /s11368-012-0469-1

Berg B, Laskowski R (2005) Litter decomposition: a guide to carbon and nutrient turnover, vol 38, 1 edn. Academic Press, Amsterdam

Bloor JM, Bardgett RD (2012) Stability of above-ground and belowground processes to extreme drought in model grassland ecosystems: interactions with plant species diversity and soil nitrogen availability. Perspect Plant Ecol Evol Syst 14:193-204. doi:10.1016/j.ppees.2011.12.001

Botta-Dukát Z (2005) Rao's quadratic entropy as a measure of functional diversity based on multiple traits. J Veg Sci 16:533-540. doi:10.1111/j.1654-1103.2005.tb02393.x

Campbell CD, Cameron CM, Bastias BA, Chen C, Cairney JWG (2008) Long term repeated burning in a wet sclerophyll forest reduces fungal and bacterial biomass and responses to carbon substrates. Soil Biol Biochem 40:2246-2252. doi:10.1016/j.soilbio.2008.04.020

Cardinale BJ, Duffy JE, Gonzalez A, Hooper DU, Perrings C, Venail P, Narwani A, Mace GM, Tilman D, Wardle DA, Kinzig AP, Daily GC, Loreau M, Grace JB, Larigauderie A, Srivastava DS, Naeem S (2012) Biodiversity loss and its impact on humanity. Nature 486:59 67. doi:10.1038/nature11148

Carrillo Y, Ball BA, Bradford MA, Jordan CF, Molina M (2011) Soil fauna alter the effects of litter composition on nitrogen cycling in a mineral soil. Soil Biol Biochem 43:1440-1449. doi:10.1016/j. soilbio.2011.03.011 
Chapman SJ, Campbell CD, Artz RRE (2007) Assessing CLPPs using MicroReSp (TM) - a comparison with biology and multi-SIR. J Soils Sediments 7:406-410. doi:10.1065/jss2007.10.259

Chapman SK, Newman GS (2009) Biodiversity at the plant-soil interface: microbial abundance and community structure respond to litter mixing. Oecologia 162:763-769. doi:10.1007/s00442-009-1498-3

Chen Y, Sun J, Xie F, Wang X, Cheng G, Lu X (2015) Litter chemical structure is more important than species richness in affecting soil carbon and nitrogen dynamics including gas emissions from an alpine soil. Biol Fertil Soils 51:791-800. doi:10.1007/s00374-015$1025-0$

Chung H, Zak DR, Reich PB, Ellsworth DS (2007) Plant species richness, elevated $\mathrm{CO}_{2}$, and atmospheric nitrogen deposition alter soil microbial community composition and function. Glob Chang Biol 13:980-989. doi:10.1111/j.1365-2486.2007.01313.x

Coq S, Souquet J-M, Meudec E, Cheynier V, Hättenschwiler S (2010) Interspecific variation in leaf litter tannins drives decomposition in a tropical rain forest of French Guiana. Ecology 91:2080-2091. doi:10.1890/09-1076.1

Cornwell WK, Cornelissen JHC, Amatangelo K, Dorrepaal E, Eviner VT et al (2008) Plant species traits are the predominant control on litter decomposition rates within biomes worldwide. Ecol Lett 11:10651071. doi:10.1111/j.1461-0248.2008.01219.x

Crawley MJ (2013) The R book. John Wiley \& Sons Inc.

Creamer RE, Stone D, Berry P, Kuiper I (2016) Measuring respiration profiles of soil microbial communities across Europe using MicroResp ${ }^{\mathrm{TM}}$ method. Appl Soil Ecol 97:36-43. doi:10.1016/j. apsoil.2015.08.004

Cutler DR, Edwards TC, Beard KH, Cutler A, Hess KT, Gibson J, Lawler JJ (2007) Random forests for classification in ecology. Ecology 88: 2783-2792

de Dato GD, De Angelis P, Sirca C, Beier C (2010) Impact of drought and increasing temperatures on soil $\mathrm{CO} 2$ emissions in a Mediterranean shrubland (gariga). Plant Soil 327:153-166. doi:10.1007/s11104009-0041-y

De Deyn GB, Raaijmakers CE, Van Ruijven J, Berendse F, Van Der Putten WH (2004) Plant species identity and diversity effects on different trophic levels of nematodes in the soil food web. Oikos 106:576-586. doi:10.1111/j.0030-1299.2004.13265.x

Díaz S, Lavorel S, de Bello F, Quetier F, Grigulis K, Robson TM (2007) Incorporating plant functional diversity effects in ecosystem service assessments. Proc Natl Acad Sci U S A 104:20684-20689. doi:10.1073/pnas.0704716104

Delmont TO, Francioli D, Jacquesson S, Laoudi S, Nesme MJ, Ceccherini MT, Nannipieri P, Simonet P, Vogel TM (2014) Microbial community development and unseen diversity recovery in inoculated sterile soil. Biol Fertil Soils 50:1069-1076. doi:10.1007/s00374-014-0925-8

Eisenhauer N, Bessler H, Engels C, Gleixner G, Habekost M, Milcu A, Partsch S, Sabais ACW, Scherber C, Steinbeiss S, Weigelt A, Weisser WW, Scheu S (2010) Plant diversity effects on soil microorganisms support the singular hypothesis. Ecology 91:485-496. doi:10.1890/08-2338.1

Eisenhauer N, Dobies T, Cesarz S, Hobbie SE, Meyer RJ, Worm K, Reich PB (2013) Plant diversity effects on soil food webs are stronger than those of elevated $\mathrm{CO}_{2}$ and $\mathrm{N}$ deposition in a long-term grassland experiment. Proc Natl Acad Sci U S A 110:6889-6894. doi:10.1073 /pnas. 1217382110

Epps KY, Comerford NB, Reeves JB III, Cropper WP Jr, Araujo QR (2007) Chemical diversity - highlighting a species richness and ecosystem function disconnect. Oikos 116:1831-1840. doi:10.1111 j.0030-1299.2007.15853.x

Fanin N, Hättenschwiler S, Barantal S, Schimann H, Fromin N (2011) Does variability in litter quality determine soil microbial respiration in an Amazonian rainforest? Soil Biol Biochem 43:1014-1022. doi:10.1016/j.soilbio.2011.01.018
Field CB, Barros VR, Mach KJ, Mastrandrea MD, Aalst MV et al. (2015) Climate change 2014: impacts, adaptation, and vulnerability. Part A: global and sectorial aspects. Contribution of Working Group II to the Fifth Assessment Report of the Intergovernmental Panel on Climate Change. (Vol. 1, pp 35-94). Cambridge, United Kingdom and New York, NY, USA: Cambridge University Press, Cambridge.

Fonte ES, Amado AM, Meirelles-Pereira F, Esteves FA, Rosado AS, Farjalla VF (2013) The combination of different carbon sources enhances bacterial growth efficiency in aquatic ecosystems. Microb Ecol 66:871-878. doi:10.1007/s00248-013-0277-1

Freiberg E (1998) Microclimatic parameters influencing nitrogen fixation in the phyllosphere in a Costa Rican premontane rain forest. Oecologia 117:9-18. doi:10.1007/s004420050625

Gao X, Pal JS, Giorgi F (2006) Projected changes in mean and extreme precipitation over the Mediterranean region from a high resolution double nested RCM simulation. Geophys Res Lett 33:L03706. doi:10.1029/2005GL024954

García-Palacios P, Prieto I, Ourcival J-M, Hättenschwiler S (2016) Disentangling the litter quality and soil microbial contribution to leaf and fine root litter decomposition responses to reduced rainfall. Ecosystems 19:490-503. doi:10.1007/s10021-015-9946-x

Garnier E, Cortez J, Billès G, Navas M-L, Roumet C, Debussche M, Laurent G, Blanchard A, Aubry D, Bellmann A, Neill C, Toussaint J-P (2004) Plant functional markers capture ecosystem properties during secondary succession. Ecology 85:2630-2637. doi:10.1890/03-0799

Gómez-Aparicio L, Zamora R, Gómez JM, Hodar JA, Castro J, Baraza E (2004) Applying plant facilitation to forest restoration: a metaanalysis of the use of shrubs as nurse plants. Ecol Appl 14:11281138. doi: $10.1890 / 03-5084$

Grace JB (2006) Structural equation modeling and natural systems. Cambridge University Press, Cambridge

Grime JP (1998) Benefits of plant diversity to ecosystems: immediate, filter and founder effects. J Ecol 86:902-910. doi:10.1046/j.13652745.1998.00306.x

Handa IT, Aerts R, Berendse F, Berg MP, Bruder A et al (2014) Consequences of biodiversity loss for litter decomposition across biomes. Nature 509:218-221. doi:10.1038/nature13247

Hättenschwiler S, Vitousek PM (2000) The role of polyphenols in terrestrial ecosystem nutrient cycling. Trends Ecol Evol 15:238-243. doi:10.1016/S0169-5347(00)01861-9

Joly FX, Fromin N, Kiikkilä O, Hättenschwiler S (2016) Diversity of leaf litter leachates from temperate forest trees and its consequences for soil microbial activity. Biogeochemistry 129:373-388. doi:10.1007 /s10533-016-0239-z

Johnson D, Booth RE, Whiteley AS, Bailey MJ, Read DJ, Grime JP, Leake JR (2003) Plant community composition affects the biomass, activity and diversity of microorganisms in limestone grassland soil. Eur J Soil Sci 54:671-678. doi:10.1046/j.1351-0754.2003.0562.x

Lange M, Eisenhauer N, Sierra CA, Bessler H, Engels C et al (2015) Plant diversity increases soil microbial activity and soil carbon storage. Nat Commun 6:6707. doi:10.1038/ncomms7707

Leff JW, Nemergut DR, Grandy AS, O'Neill SP, Wickings K, Townsend AR, Cleveland CC (2012) The effects of soil bacterial community structure on decomposition in a tropical rain forest. Ecosystems 15: 284-298. doi:10.1007/s10021-011-9510-2

Lionello P, Giorgi F (2007) Winter precipitation and cyclones in the Mediterranean region: future climate scenarios in a regional simulation. Adv Geosci 12:153-158. doi:10.5194/adgeo-12-153-2007

Lloret F, Mattana S, Yuste JC (2015) Climate-induced die-off affects plant-soil-microbe ecological relationship and functioning. FEMS Microbiol Ecol 91:1-12. doi:10.1093/femsec/fiu014

Loreau M (2001) Microbial diversity, producer-decomposer interactions and ecosystem processes: a theoretical model. Proc R Soc London B Biol Sci 268:303-309. doi:10.1098/rspb.2000.1366 
Lorentzen S, Roscher C, Schumacher J, Schulze ED, Schmid B (2008) Species richness and identity affect the use of aboveground space in experimental grasslands. Perspect Plant Ecol Evol Syst 10:73-87. doi:10.1016/j.ppees.2007.12.001

Meier CL, Bowman WD (2008) Links between plant litter chemistry, species diversity, and below-ground ecosystem function. Proc Natl Acad Sci 105:19780-19785. doi:10.1073/pnas.0805600105

Meier CL, Bowman WD (2010) Chemical composition and diversity influence non-additive effects of litter mixtures on soil carbon and nitrogen cycling: implications for plant species loss. Soil Biol Biochem 42:1447-1454. doi:10.1016/j.soilbio.2010.05.005

Milcu A, Allan E, Roscher C, Jenkins T, Meyer ST et al (2013) Functionally and phylogenetically diverse plant communities key to soil biota. Ecology 94:1878-1885. doi:10.1890/12-1936.1

Mokany K, Ash J, Roxburgh S (2008) Functional identity is more important than diversity in influencing ecosystem processes in a temperate native grassland. J Ecol 96:884-893. doi:10.1111/j.13652745.2008.01395.x

Montès N, Maestre FT, Ballini C, Baldy V, Gauquelin T, Planquette M, Greff S, Dupouyet S, Perret J-B (2008) On the relative importance of the effects of selection and complementarity as drivers of diversityproductivity relationships in Mediterranean shrublands. Oikos 117: 1345-1350. doi:10.1111/j.0030-1299.2008.16910.x

Niklaus PA, Alphei J, Kampichler C, Kandeler E, Körner C, Tscherko D, Wohlfender $M$ (2007) Interactive effects of plant species diversity and elevated $\mathrm{CO}_{2}$ on soil biota and nutrient cycling. Ecology 88: 3153-3163. doi:10.1890/06-2100.1

Pailler A, Vennetier M, Torre F, Ripert C, Guiral D (2014) Forest soil microbial functional patterns and response to a drought and warming event: key role of climate-plant-soil interactions at a regional scale. Soil Biol Biochem 70:1-4. doi:10.1016/j. soilbio.2013.12.003

Petchey OL, Gaston KJ (2006) Functional diversity: back to basics and looking forward. Ecol Lett 9:741-758. doi:10.1111/j.14610248.2006.00924.x

Porazinska DL, Bardgett RD, Blaauw MB, Hunt HW, Parsons AN, Seastedt TR, Wall DH (2003) Relationships at the abovegroundbelowground interface: plants, soil biota, and soil processes. Ecol Monogr 73:377-395. doi:10.1890/0012-9615(2003)073[0377 :RATAIP]2.0.CO;2

Reich PB, Knops J, Tilman D, Craine D, Ellsworth D et al (2001) Plant diversity enhances ecosystem responses to elevated $\mathrm{CO}_{2}$ and nitrogen deposition. Nature 410:809-812. doi:10.1038/35071062

Rodríguez-Loinaz G, Onaindia M, Amezaga I, Mijangos I, Garbisu C (2008) Relationship between vegetation diversity and soil functional diversity in native mixed-oak forests. Soil Biol Biochem 40:49-60. doi:10.1016/j.soilbio.2007.04.015

Roscher C, Schumacher J, Gubsch M, Lipowsky A, Weigelt A, Buchmann N, Schmid B, Schulze ED (2012) Using plant functional traits to explain diversity-productivity relationships. PLoS One 7: e36760. doi:10.1371/journal.pone.0036760

Rosseel Y (2012) Lavaan: an R package for structural equation modeling. J Stat Softw 48:1-36. doi:10.18637/jss.v048.i02

Salamon JA, Schaefer M, Alphei J, Schmid B, Scheu S (2004) Effects of plant diversity on Collembola in an experimental grassland ecosystem. Oikos 106:51-60. doi:10.1111/j.0030-1299.2004.12905.x
Sardans J, Penuelas J, Estiarte M (2006) Warming and drought alter soil phosphatase activity and soil $\mathrm{P}$ availability in a Mediterranean shrubland. Plant Soil 289:227-238. doi:10.1007/s11104-006-9131-

Schimel JP, Cates RG, Ruess R (1998) The role of balsam poplar secondary chemicals in controlling soil nutrient dynamics through succession in the Alaskan taiga. Biogeochemistry 42:221-234. doi:10.1023/A:1005911118982

Schumacher J, Roscher C (2009) Differential effects of functional traits on aboveground biomass in semi-natural grasslands. Oikos 118: 1659-1668. doi:10.1111/j.1600-0706.2009.17711.x

Steinauer K, Tilman D, Wragg PD, Cesarz S, Cowles JM, Pritsch K, Reich PB, Weisser WW, Eisenhauer N (2015) Plant diversity effects on soil microbial functions and enzymes are stronger than warming in a grassland experiment. Ecology 96:99-112. doi:10.1890/140088.1

Swift MJ, Heal OW, Anderson JM (1979) Decomposition in terrestrial ecosystems. University of California Press

Takhur MP, Milcu A, Manning P, Niklaus PA, Roscher C et al (2015) Plant diversity drives soil microbial biomass carbon in grassland irrespective of global environmental change factors. Glob Chang Biol 21:4046-4085. doi:10.1111/gcb.13011

van der Plas F, Manning P, Allan E, Scherer-Lorenzen M, Verheyen K et al (2016) Jack-of-all-trades effects drive biodiversity-ecosystem multifunctionality relationships in European forests. Nature Comm 7:11109. doi:10.1038/ncomms11109

Violle C, Navas M-L, Vile D, Kazakou E, Fortunel C, Hummel I, Garnier E (2007) Let the concept of trait be functional! Oikos 116:882-892. doi:10.1111/j.2007.0030-1299.15559.x

Vogel A, Eisenhauer N, Weigelt A, Scherer-Lorenzen N (2013) Plant diversity does not buffer drought effects on early-stage litter mass loss rates and microbial properties. Global Change Biol doi. doi: $10.1111 / \mathrm{gcb} .12225$

Wardle DA (2002) Communities and ecosystems: linking the aboveground and belowground components. Princeton University Press

Wardle DA, Bonner KI, Barker GM, Yeates GW, Nicholson KS, Bardgett RD, Watson RN, Ghani A (1999) Plant removals in perennial grassland: vegetation dynamics, decomposers, soil biodiversity, and ecosystem properties. Ecol Monogr 69:535-568. doi:10.1890/00129615(1999)069[0535:PRIPGV]2.0.CO;2

Wardle DA, Bonner KI, Nicholson KS (1997) Biodiversity and plant litter: experimental evidence which does not support the view that enhanced species richness improves ecosystem function. Oikos 79: 247-258. doi: $10.2307 / 3546010$

Xiang S-R, Doyle A, Holden PA, Schimel JP (2008) Drying and rewetting effects on $\mathrm{C}$ and $\mathrm{N}$ mineralization and microbial activity in surface and subsurface California grassland soils. Soil Biol Biochem 40:2281-2289. doi:10.1016/j.soilbio.2008.05.004

Yuste JC, Fernandez-Gonzalez AJ, Fernandez-Lopez M, Ogaya R, Penuelas J, Sardans J, Lloret F (2014) Strong functional stability of soil microbial communities under semiarid Mediterranean conditions and subjected to long-term shifts in baseline precipitation. Soil Biol Biochem 69:223-233. doi:10.1016/j.soilbio.2013.10.045 